\title{
COMPARISON OF TROPONIN LEVELS IN ISOLATED MIDDLE CEREBRAL ARTERY AND ANTERIOR SYSTEM TANDEM OCCLUSION TREATED WITH MECHANICAL THROMBECTOMY
}

\author{
Nihat ŞENGEZE*, Semih GIRAY**, Yusuf İNANÇ**, Alper EREN**, Sedat YAȘín** \\ Süleyman Demirel University Faculty of Medicine, Department of Neurology, Isparta, TURKEY \\ Gaziantep University Faculty of Medicine, Department of Neurology, Gaziantep, TURKEY
}

\begin{abstract}
INTRODUCTION: Ischemic stroke is the most common disability worldwide and the second most common cause of mortality. One of the major causes of mortality in patients with ischemic stroke is cardiac complications. However, high levels of troponin may be caused in patients with ischemic stroke and many of the systemic diseases that has a risk for the stroke. In this study, we aimed to investigate troponin levels of stroke patients who were treated with mechanical thrombectomy and the resulting risk factors for stroke, mortality and physical dependence at the end of the third month in tandem and M1 occlusions.

METHODS: In this study, troponin values are examined retrospectively in stroke patients with tandem occlusion of the anterior circulation and middle cerebral artery M1 occlusions, who were treated between January 2015 and February 2019. SPSS Windows 23 package program was used in the statistical analysis of the data obtained from the study. Troponin values in tandem and middle cerebral artery occlusion were compared with chi-square method. Results were evaluated at $95 \%$ confidence interval and $\mathrm{p}<0.05$ level of significance.

RESULTS: When the mortality rates between tandem and MCA occlusions were examined at the end of the third month, mortality rates were higher in tandem occlusions and there was a statistically significant difference between the two groups (p: 0.027). There was no significant difference between tandem and MCA occlusions in terms of troponin values (p: 0.63). Patients with troponin values above $0.028 \mathrm{ng} / \mathrm{mL}$ had significantly higher mortality at 3 months.

DISCUSSION and CONCLUSION: There is a relationship between mortality and elevation of troponin levels in patients who had tandem and MCA occlusions. However, there was no difference between tandem and MCA occlusions in terms of troponin values significantly. There is a need to further study the impact of ischemic stroke on troponin levels with randomized, controlled studies.

Keywords: Tandem occlusion, middle cerebral artery occlusion, troponin level, endovascular treatment, ischemic stroke, mechanical thrombectomy.

\section{MEKANIK TROMBEKTOMI İLE TEDAVI EDILEN İZOLE ORTA SEREBRAL ARTER VE ÖN SISTEM TANDEM OKLÜZYONU OLGULARINDAKI TROPONIN DÜZEYLERININ KARŞILAŞTIRILMASI}

\section{ÖZET}

GİRIŞ ve AMAÇ: İskemik inme tüm dünyada en sık sakatlık bırakan ve ikinci sıklıkta mortaliteye neden olan hastalıktır. İskemik inme geçiren hastalarda mortalitenin önemli nedenlerinden biri de kardiyak komplikasyonlardır. Troponin, akut miyokard infarktüsünün tanısında ve akut koroner semptomları olan hastaların risk sıralamasında kullanılan yüksek duyarlılı̆̆ ve özgünlüğü olan bir belirteçtir. Bununla birlikte, iskemik inmeli hastalarda troponin yüksekliğine inme için risk oluşturan sistemik hastalıkların birçoğu neden olabilmektedir. Biz çalışmamızda mekanik trombektomi ile tedavi ettiğimiz tandem oklüzyonlar ve orta serebral arter M1 oklüzyonlarındaki troponin seviyelerini, inme risk faktörlerini, üçüncü ay sonundaki mortalite ve fiziksel bağımlılı̆̆ incelemeyi amaçladık.

YÖNTEM ve GEREÇLER: Çalışmada Ocak 2015- Şubat 2019 yılları arasından hastanemize başvuran ve mekanik trombektomi ile tedavi edilen ön sistem tandem oklüzyonlar ile orta serebral arter M1 oklüzyonlarının başvuru anındaki troponin değerleri

\footnotetext{
Corresponding author: Nihat Şengeze, MD. Süleyman Demirel University Faculty of Medicine, Department of Neurology, Isparta, TURKEY

Telephone: +902464417280 E-mail: nihatsengeze@yahoo.com

Received: $13.06 .2019 \quad$ Accepted: 30.07.2019

This article should be cited as following: Şengeze N, Giray S, İnanç Y, Eren A, Yaşin S. Comparison of troponin levels in isolated middle cerebral artery and anterior system tandem occlusion treated with mechanical thrombectomy. Turkish Journal of Cerebrovascular Diseases 2019 ; 25 (2): $113-117$. doi: $10.5505 /$ tbdhd.2019.53824
} 
retrospektif olarak incelendi. Çalışmada elde edilen verilerin istatistiksel analizinde SPSS ( Statistical Package for Social Sciences) Windows 23 paket programı kullanıldı. Tandem ve orta serebral arter tıkanıklığındaki troponin değerleri ki-kare yöntemi ile karşılaştırıldı. Sonuçlar \%95'lik güven aralığında, anlamlılık p<0,05 düzeyinde değerlendirildi.

BULGULAR: Tandem ve MCA oklüzyonları arasında 3. ay sonunda mortalite oranları incelendiğinde, tandem oklüzyonlarda mortalite oranları daha yüksekti ve iki grup arasında istatistiksel olarak anlamlı farklılık bulunmaktaydı (p: 0.027). Tandem ve MCA oklüzyonları arasında troponin değerleri açısından anlamlı farklılık bulunmadı (p: 0.63). Troponin değerleri 0.028 ng/mL üzerindeki hastalarda anlamlı oranda 3. aydaki mortalite daha yüksekti.

TARTIŞMA ve SONUÇ: Geniş damar oklüzyonuna sebep olan ön sistem tandem oklüzyon ve MCA oklüzyonlarında troponin değerlerindeki yükseklik ile mortalite arasında anlamlı bir ilişki bulunmaktadır. Ancak tandem oklüzyonlar ve MCA oklüzyonları arasında troponin değerleri açısından anlamlı bir farklılık saptanmamıştır. İskemik inme ve troponin ilişkisi üzerine randomize kontrollü, daha çok hasta sayısı içeren ve inme subtiplerine göre incelemenin yapıldığı prospektif çalışmalara ihtiyaç vardır.

Anahtar Sözcükler Tandem oklüzyon, orta serebral arter oklüzyonu, troponin seviyesi, endovasküler tedavi, iskemik inme, mekanik trombektomi.

\section{INTRODUCTION}

Ischemic stroke is a disease which causes disability the most often throughout the world, followed by mortality as second most often. One of the major causes of mortality in patients with ischemic stroke is cardiac complications. (1)

Troponin is a marker which has a high sensitivity and specificity used in the diagnosis of acute myocardial infarction and risk assessment of patients with acute coronary symptoms. Ischemic stroke and concomitant risk factors in these patients can increase troponin. Many studies were conducted recently regarding increased troponin in ischemic stroke (2). In these studies, two main reasons for increased troponin in ischemic stroke patients come to the fore. The first is increased troponin due to ischemic myocardial injury (tachyarrhythmias, hypertensive crisis, respiratory dysfunction, etc.) and the second is due to nonischemic myocardial injury (increased sympathoadrenal activity, etc.) $(3,4)$. The pathophysiology of troponin elevation in ischemic strokes is not yet clearly understood. Different results were reported between troponin elevation and stroke prognosis $(1,4,5)$. In this study, we aimed to investigate chitroponin levels, stroke risk factors, mortality and physical dependence at the end of the third month in tandem occlusions and middle cerebral artery M1 occlusions that we treated with endovascular treatment.

\section{MATERIAL AND METHODS}

In this study, the troponin values, at the admission moment, of the anterior system tandem occlusions (atherosclerotic and dissection) and isolated middle cerebral artery M1 occlusions admitted to our hospital between January 2015 and February 2019 and treated by mechanical thrombectomy were evaluated retrospectively. A total of 59 patients were included in the study. The patients diagnosed with acute myocardial infarction were excluded from the study. In all patients, hemorrhagic stroke and other causes that fall within the scope of stroke differential diagnosis were excluded using CT.

The assent of Gaziantep University, Faculty of Medicine, Ethical Committee of Clinical Researches dated 03.04.2019 numbered 2019/162 was received for the study.

Serum Troponin I values were obtained from venous blood samples taken at the time of admission of patients to the acute ischemic stroke clinic. Patients were evaluated for stroke risk factors, stroke weight and side, and modified rankin scale at the end of the third month.

The National Institute of Health Stroke Scale (NIHSS) was used to assess stroke weight and the Modified Rankin Scale (mRS) was used as a prognostic marker.

Electrocardiography (ECG) recordings of each patient were examined and ECG findings were recorded. In addition, patients with signs of ischemic heart disease on ECG and arrhythmia other than atrial fibrillation (AF) were excluded from the study. Echocardiography and cardiac examination results of each patient were evaluated by cardiology department.

SPSS (Statistical Package for Social Sciences) Windows 23 package program was used for the statistical analysis of the data obtained from the study. Troponin values in tandem and middle cerebral artery occlusion were compared using chisquare method. Results were evaluated at 95\% 
confidence interval and the significance was evaluated at $\mathrm{p}<0.05$ level.

\section{RESULTS}

$44(74.6 \%)$ out of 59 patients included in the study were patients with MCA occlusion and 15 (25.4\%) thereof were patients with tandem occlusion. Average age of all patients was 62.5 \pm 12.2 . $32(54.2 \%)$ of all patients were female, and their admission NIHSS score was $18 \pm 4.6,35$ $(59.3 \%)$ of patients admitted with right side weakness and 13 (22\%) of patients received IV thrombolitic treatment after admission. The mRS score at the end of 3rd month was 6 in $25 / 42.2 \%$ ) of patients. The mRS score for $26(44.1 \%)$ patients out of all at the end of 3rd month was $\mathrm{mRS} \leq 3$ and they had low physical dependence (Table I and II).

When the mortality rates were examined between the two groups at the end of the third month, there was a mortality of $10(66.7 \%)$ in tandem occlusions and $15(34.1 \%)$ in MCA occlusions, and there was a statistically significant difference between the two groups (p: 0.027).

Troponin levels were found as $0.55 \pm 3.93$ $\mathrm{ng} / \mathrm{mL}$ in both groups. No significant difference was found between tandem and MCA occlusions in terms of troponin values (p: 0.63) (Mann-Whitney U test) (Table III).

Mortality was observed in $10(66.7 \%)$ of 15 patients whose troponin level was greater than $0.028 \mathrm{ng} / \mathrm{mL}$ in 3rd month, while for the patients whose troponin level was under that value, the mortality was observed in 15 patients (34.1\%) in 3rd month. Patients with troponin values above $0.028 \mathrm{ng} / \mathrm{mL}$ had statistically higher mortality in 3 month $(p=0.027)$ (Chi-square test).

\section{DISCUSSION}

Troponin elevation in patients with ischemic stroke was reported to range from $5-34 \%$ in several studies. Characteristically, chest pain, epigastric pain, pain spreading to the arm are complaints in patients with acute myocardial infarction, while some patients have atypical symptoms and even silent ischemia cases can be seen. From this perspective, troponin elevation or similarity of complaints can be seen also in stroke patients (6).

Although not fully understood, non-ischemic neurogenic myocardial damage in stroke patients is thought to result from increased sympathetic activity resulting from cortical-induced autonomic
Table I. Distribution of demographic data of patients by occlusion site.

\begin{tabular}{llll}
\hline \multirow{2}{*}{$\begin{array}{l}\text { Demographic and } \\
\text { follow-up data }\end{array}$} & \multicolumn{2}{c}{ Site of Occlusion } & \\
& MCA & Tandem & \\
& N(\%) & N(\%) & $\mathbf{P}^{*}$ \\
\hline Atrial Fibrillation & $15(78.9)$ & $4(21.1)$ & 0.595 \\
Hypertension & $29(85.3)$ & $5(14.7)$ & $0.027^{*}$ \\
Smoking & $9(60)$ & $6(40)$ & 0.133 \\
Diabetes & $14(56)$ & $11(44)$ & 0.05 \\
Coronary artery disease & $13(81.3)$ & $3(18.8)$ & 0.473 \\
Hyperlipidemia & $17(73.9)$ & $6(26.1)$ & 0.925 \\
Third month mRS $\leq 3$ & $22(84.6)$ & $4(15.4)$ & 0.116 \\
Mortality in 3rd month & $15(60)$ & $10(40)$ & $0.027^{*}$ \\
\hline *Chi-square test & & &
\end{tabular}

Table II. Laboratory, imaging and clinical data of patients at the moment of admission by occlusion site.

\begin{tabular}{|c|c|c|c|}
\hline \multirow[b]{2}{*}{$\begin{array}{l}\text { Admission values } \\
\text { patients }\end{array}$} & \multicolumn{2}{|c|}{ Site of Occlusion } & \multirow[b]{2}{*}{$\mathbf{P}^{*}$} \\
\hline & $\begin{array}{l}\text { MCA } \\
\text { Mean } \pm \text { SD } \\
\end{array}$ & $\begin{array}{l}\text { Tandem } \\
\text { Mean } \pm \text { SD }\end{array}$ & \\
\hline CT aspect score & $9.25 \pm 0.9$ & $7.2 \pm 1.4$ & 0.053 \\
\hline Admission NIHSS & $16.5 \pm 3.3$ & $22.7 \pm 4.6$ & 0.051 \\
\hline Glucose & $172.8 \pm 76.1$ & $163.6 \pm 64$ & 0.696 \\
\hline Leucocyte & $9831 \pm 3845$ & $11790 \pm 4076$ & 0.828 \\
\hline Platelet & $262.9 \pm 77.8$ & $246.4 \pm 50.4$ & 0.052 \\
\hline Hemoglobin & $12.5 \pm 1.8$ & $14.1 \pm 1.6$ & 0.382 \\
\hline Creatinine & $0.8 \pm 0.3$ & $0.7 \pm 0.1$ & 0.141 \\
\hline
\end{tabular}

*Mann Whitney U test

Table III. Comparison of troponin values and occlusion site of patients.

\begin{tabular}{lllll}
\hline & Site of Occlusion & N & Mean & SD \\
\hline \multirow{2}{*}{ Troponin } & MCA & 44 & 0,72 & 4,55 \\
& Tandem & 15 & 0,05 & 0,13 \\
\hline
\end{tabular}

Mann-Whitney U test (p: 0.63)

imbalance, leading to cardiac contractile band necrosis (7).

In another study, it was reported that catecholamine increase and activation of the sympatho-adrenal system significantly contribute to myocardial damage in stroke patients (3).

The pathophysiology of troponin elevation in ischemic stroke is not fully elucidated yet. Troponin elevation in stroke patients may occur due to numerous causes such as congestive heart failure, chronic renal failure, chronic obstructive pulmonary disease, pulmonary embolism, sepsis, atrial fibrillation. However, current studies suggest that troponin elevation in stroke patients may have a prognostic value on mortality independent from acute myocardial infarction and renal failure (1).

In a meta-analysis made regarding the prediction of troponin elevation on mortality in stroke patients, it was suggested that cardiac 
troponin increases at the time of first admission may be effective in determining the risk of premature death in stroke patients (1).

In other studies investigating the association of cardiac troponin increases with poor prognosis and mortality, the mortality at the end of 30 days in stroke cases with increased troponin was found significantly high $(1,8,9,10)$. The long-term mortality result was also investigated in a separate study (3-year period) and the mortality was found higher in the patients with increased troponin at the time of admission. In acute stroke cases with increased troponin, both short- and long-term mortality was reported to be higher than in the group without increased troponin $(11,12)$. Also in our study, the mortality rate was observed statistically significantly higher at the end of the third month in cases with troponin values greater than $0.028 \mathrm{ng} / \mathrm{mL}(\mathrm{p}=0.027)$. However, no comparison was made because of the small number of tandem and MCA patient groups.

According to another study evaluating the relationship between troponin elevation and ischemic stroke, it is suggested that troponin I levels in patients with ischemic stroke may be seen independently of a cardiac disease, but generally, troponin I levels higher than $2 \mathrm{ng} / \mathrm{mL}$ are not associated with acute ischemic stroke, and a comprehensive assessment of coronary artery disease in these patients is recommended (7).

In another meta-analysis, cardiac troponin elevation was also reported to be associated with increased risk of late cerebral ischemia and death in patients with spontaneous subarachnoid hemorrhage (13). In a study conducted by Xu et al., troponin elevations were found to be associated with intracranial herniation in patients followed up with intracerebral hemorrhage. It was stated that the possibility of cerebral herniation should be considered in patients with large hematoma and troponin elevation (14).

In only two recent studies, it was reported that elevated troponin levels may be a marker of coronary atherosclerotic plaques in acute stroke patients. However, there are conflicting results in other studies. The general opinion is that autonomic dysfunction due to catecholamine discharge causes cardiac impairment $(5,15,16)$.

In Trelas study, in which stroke patients were also evaluated in terms of coronary angiography, the patients admitted to the stroke clinic with elevated troponin (TcT:> $0.05 \mathrm{ng} / \mathrm{l}$ ) were compared to patients with acute coronary syndrome without
ST elevation. Among the patients with troponin elevation, 85\% coronary lesions were detected in patients with acute coronary syndrome without ST elevation, and in 7 (24\%) of 29 patients with troponin elevation, a coronary lesion (more than $50 \%$ stenosis) was found, and two-fold higher levels of troponin was found in these patiens than those without any coronary artery lesions (17). In this study, one reason for troponin elevation in acute stroke patients was stated to be simultaneous coronary artery embolism and the other cause was myocardial damage due to autonomic imbalance caused by catecholamines, when renal impairment is excluded (18). Also in the Trelas study and the study conducted by Meyer et al., when the relationship between troponin increase and brain imaging was examined, it was reported that especially right-sided insular lesions were found have caused cardiac damage by disruption of autonomic balance and increased sympoto-adrenal activity $(18,19,20)$. In the TRELAS sub-study, it was stated that noninvasive cardiac MRI could also provide useful information to identify stroke patients with or without acute coronary syndrome (21). In our study, no statistically significant relationship was found between the stroke side and elevation of troponin.

Although there was a significant relationship between increased infarct volume and increased troponin volume in some studies comparing troponin increase with infarct volume in acute stroke patients, this relationship could not be found in a study in which more patient groups were included. Therefore, there is no clarity on this subject according to current studies (6). In our study, when troponin values were compared between anterior system tandem occlusions and isolated MCA occlusions, no significant difference was found between the two groups.

Current data support the view that the troponin elevation in stroke patients is a secondary response to the development of myocardial ischemia triggered by the systemic response (such as increased catecholamine) resulting from intracranial injury (infarct, hematoma, cerebral edema, etc.) rather than the occlusion site and the affected cerebral area.

There is a need for randomized controlled prospective studies on the relationship between ischemic stroke and troponin that include more number of patients and in which examination is made according to sub-types of stroke.

As conclusion, elevated troponin can be seen 
in acute ischemic stroke patients with large vessel occlusion who admit to emergency department. In cases with elevated troponin, it may be necessary to follow-up this value to exclude underlying cardiac pathology.

\section{REFERENCES}

1. Fan Y, Jiang M, Gong D, et al. Cardiac troponin for predicting all-cause mortality in patients with acute ischemic stroke: a meta-analysis. Biosci Rep. 2018;38(2). pii: BSR20171178. doi: 10.1042/BSR20171178. Print 2018 Apr 27

2. Mercimek T.0, Çelebi L.G, Gökyiğit M. Akut İskemik İnme ve Serum Troponin I İlişkisi. Turkiye Klinikleri J Neur 2014; 9(2): 60-66.

3. Barber M, Morton JJ, Macfarlane PW, et al. Elevated troponin levels are associated with sympathoadrenal activation in acute ischaemic stroke. Cerebrovasc Dis 2007; 23(4): 260266.

4. Su YC, Huang KF, Yang FY, et al. Elevation of troponin I in acute ischemic stroke. PeerJ. 2016; 4: e1866.

5. Chang A, Ricci B, Grory BM, et al. Cardiac Biomarkers Predict Large Vessel Occlusion in Patients with Ischemic Stroke. J Stroke Cerebrovasc Dis. 2019; 28(6): 1726-1731.

6. Král M, Šaňák D, Veverka T, et al. Troponin T: Correlation with location and volume of acute brain infarction. Int J Cardiol. 2015; 15; 181: 127-132.

7. VanHouten J, Fricker G, Collins B, et al. Circulating Troponin I Level in Patients with Acute Ischemic Stroke. Curr Neurol Neurosci Rep. 2018; 20;1 8(6): 32.

8. Batal 0 , Jentzer J, Balaney $B$, et al. The prognostic significance of troponin I elevation in acute ischemic stroke. J Crit Care. 2016; 31(1): 41-47.

9. Thalin C, Rudberg A. S, Johansson F, et al. Elevated troponin levels in acute stroke patients predict long-term mortality. Journal of Stroke and Cerebrovascular Diseases. 2015; 24(10): 2390-2396.

10. Jensen JK, Atar D, Mickley H. Mechanism of troponin elevations in patients with acute ischemic stroke. Am J Cardiol 2007; 99: 867e870.
11. Wrigley P, Khoury J, Eckerle B, et al. Prevalence of Positive Troponin and Echocardiogram Findings and Association With Mortality in Acute Ischemic Stroke. Stroke. 2017;48(5):1226-1232.

12. Dous GV, Grigos AC, Grodman R. Elevated troponin in patients with acute stroke - Is it a true heart attack?. Egypt Heart J. 2017; 69(3): 165-170.

13. Zhang L, Wang Z, Qi S. Cardiac Troponin Elevation and Outcome after Subarachnoid Hemorrhage: A Systematic Review and Meta-analysis. J Stroke Cerebrovasc Dis. 2015; 24(10): 2375-2384.

14. $\mathrm{Xu} \mathrm{M}$, Lin J, Wang $\mathrm{D}$, et al. Cardiac troponin and cerebral herniation in acute intracerebral hemorrhage. Brain Behav. 2017; 7(6).

15. Yoshimura S, Toyoda K, Ohara T, et al. Takotsubo cardiomyopathy in acute ischemic stroke. Ann Neurol 2008; 64: 547-554.

16. Hofmann Bowman MA, Liao JK. Relative Lack of Culprit and Obstructive Coronary Lesions in Patients With Acute Ischemic Stroke and Elevated Cardiac Troponin. Circulation. 2016; 133(13): 1228-1229.

17. Mochmann HC, Scheitz JF, Petzoid GC, et al. Coronary angiographic findings in acute ischemic stroke patients with elevated cardiac troponin: clinical perspective. Circulation. 2016; 133: 1264-1271.

18. Scheitz JF, Mochmann HC, Nolte $\mathrm{CH}$, et al. Troponin elevation in acute ischemic stroke (TRELAS)--protocol of a prospective observational trial. BMC Neurol. 2011; 8; 11: 98.

19. Meyer S, Strittmatter M, Fischer C, et al. Lateralization in autonomic dysfunction in ischemic stroke involving the insular cortex. Neuroreport. 2004; 9; 15(2): 357-361.

20. Ay H, Koroshetz WJ, Benner $T$, et al. Neuroanatomic correlates of stroke-related myocardial injury. Neurology. 2006; 9; 66(9): 1325-1329.

21. Haeusler KG, Jensen C, Scheitz JF, et al. Cardiac Magnetic Resonance Imaging in Patients with Acute Ischemic Stroke and Elevated Troponin: A TRoponin ELevation in Acute Ischemic Stroke (TRELAS) Sub-Study. Cerebrovasc Dis Extra. 2019; 30; 9(1): 19-24. 